\title{
Communicating and Resisting Oppression: Using Drama for Communication Skills and Social Consciousness in Language Classrooms
}

\author{
Rangehbok Lyngwa, Paonam Sudeep Mangang
}

\begin{abstract}
The highest education is that which does not merely give us information but makes our life in harmony with all existence. (Rabindranath Tagore) This statement made by Tagore highlights the most prominent objective of education as a means not only to provide information but most importantly to imbibe the sense of respect, love and fellow feeling that is the main ingredient required to usher in peace and harmony in a nation. Here, information denotes the skills that education imparts whereas the harmony that he refers to speaks of a social responsibility that can bring about harmony and national development. However the syllabi in most of the educational institutions related with language learning and communication skills especially in technical institutions are questionable as to whether they serve to impart both these aspects. A formidable query arises as to whether we are moulding humans equipped with technical and social skills or are we merely manufacturing living and breathing machines sans any form of moral and emotional attachment to their surroundings. The present paper is a case study conducted to determine whether the inclusion of literature in the form of drama in a language learning classroom for engineering students would help to hone the communication skills and inculcate the social responsibility and imbibe consciousness in them.
\end{abstract}

Keywords: Communication, Consciousness, Inter-personal, Non-verbal, Oppression.

\section{INTRODUCTION}

Although India has emerged as a super power with its developments in trade, economy and technological advancement yet lately, it has seen its fair share of injustices and oppression meted out to the marginalized classes. Minority communities have had to bear the brunt of hate crimes targeted against them by dominating agencies. On the other hand women have been at the receiving end of every form of oppression. Such incidents tends to raise questions as to whether the educational system of the country is efficient enough to sensitise the students about such issues and alter their perspectives on whether to counter such anti-social issues and react to them. If one has to examine the syllabi of many technical institutions in the country one is surely going to encounter a dehumanized pattern that delves mainly only on the need and objective to equip young students with technical skills. This poses a serious assumption as to whether the complacent attitude that we Indians have developed to anti-social situations can be seriously linked to the way we are educated and trained in our institutions. Are we institutionalised to look at an act of injustice with indifference or is a system created where we are made to believed that such situations are normalized conditions that exist in the vicinities of our social environments.

\section{HUMANITIES AND ENGINEERING}

Every technical institute has a humanities department. The said department is established to cater to the needs of the students in terms of skills related with communication and social skills. The main objective of the department is to imbibe the four skills of language learning - Reading, Writing, Listening and Speaking. One important skill that is also included in the subject is to teach students the value of public relations. (The department's syllabi include practical topics like public speaking, group discussions, facing Interviews, giving presentations etc. No doubt the skills inculcated are defined by their practicality and relevance in the students' future need when he/she ventures into the world to look for a job. However as technical as the design of the syllabi is, there is an implication that sees the concept of humanity which is the very essence of the department neglected from the regular pattern. Apart from this, literature which imparts the most important aspect of social awareness and civic responsibility finds very little space in the syllabi, as a matter of fact in some institutes its existence is actually reduced to nothing. Therefore it is only justified to ask if the inclusion of Literature in the regular pattern would help to achieve the ends of teaching communication and imbibing a sense of social responsibility. William J. Long while trying to explain the significance of literature thus states:

Behind every book is a man; behind the man is the race; and behind the race are the natural and social environments whose influence is unconsciously reflected. (Long. 2015)

Long's statement implies the connection that literature has with its social, cultural, political and even the economic environment. With this perspective at hand it is understood that when one studies literature he or she is made aware and thus empowered with a sense to react, that is to promote anything that is good and condemn anything that is altogether bad. This particular characteristic of literature explains as to why its inclusion in the syllabi of educational institutions is essential and important.

Apart from that literature has always been a source of language learning where right from the kindergarten, nursery rhymes which are an essential component of literature is actually used as a tool to instruct the young learners to interact in the target language. Language learning and engineering studies have become synonymous as globalization opens up avenues for young aspiring technicians and professionals to work abroad. 


\section{Communicating and Resisting Oppression: Using Drama for Communication Skills and Social Consciousness in Language Classrooms}

For that reason it is essential for the syllabi to cater to such needs that will help them obtain a respectable position in reputed industries and organizations. Although most prescribed syllabi cater to these needs yet the dominating technical aspect of the pattern makes learning boring and cumbersome. In such situations students treat the subject only as a 'pass mark' subject. In this regard therefore would the inclusion of literature make language learning more interesting and engaging? The case study is conducted to examine whether language learners in technical classes prefer the inclusion of literature in their regular pattern or whether the existing one serves its purpose. The case study will also answer questions as to whether the use of drama in the class helps them to imbibe and inculcate proper communication techniques while awakening them to certain social realities and also allowing them to voice concerns about certain social issues presented in the plays.

\section{DRAMA AS A TOOL}

For the case study Drama as a genre of literature has been chosen as a potential source of language learning and to raise social consciousness. Many playwrights right from the genius that is Shakespeare to the more abstract 'Avant-garde' contemporary dramatists and writers have utilised this genre to its maximum potential in order to highlight the characteristic of an age or a period defined by the multitude of social upheavals that have taken place. In such an instance it can be seen as a formidable source of social consciousness. A name synonymous with propagating social issues through drama is Augusta Boal who developed the 'Theatre of the Oppressed' a theatre form that allowed the people to express concern and react against any form of inequality that existed in society. His works defined by their interactive character, turned his spectators to 'Spect-actors' whereby members of the audience reacted in the spur of the moment to any particular issue portrayed through a play. This also paved a way for 'Legislative theatre' that allowed the audience to get involve in critically examining existing laws and regulations. There have also been developments of theatre forms that were daring and practical like the 'In-yer-face' theatre which dealt with the bare facts and realities of a social system plagued with violence, sex and exploitation. In India too, many playwrights have evolved over the years the likes of which oppression, marginalization and corruption. Such literary works have allowed audience to be made aware of their social surroundings and environment thus paving way for reaction and protest which is always a healthy sign of democracy.

The role that drama can play in honing the communications skills of the students also cannot be undermined. According to Maley (2005) when drama is used in a language classroom it naturally integrates communication. The use of drama integrates listening skills and verbal communication to a major extent. Participants intensively listen to the dialogues and in interacting with each other learn the benefits of proper sentence construction, proper usage of grammar and expression. The comfort to express themselves originates from a pre-existent script. Maley (2005), also stresses on the aspect of 'mime' which is an important characteristic of Drama, as a promoter of non-verbal communication techniques. According to Holden portray the reality of the Indian society immersed in

(1981), drama is defined as "any kind of activity where learners are asked either to portray themselves or to portray someone else in an imaginary situation." This imaginary situation is however drawn from real life and allowing the learner to take part in it allows him/her to better understand and therefore provides a platform for expression.

Prose has not been chosen for the case study due to its expansive nature and descriptive characteristic. Poetry on the other hand cannot be considered due to its independent nature and the complex form of expression that poets develop in their poems. Drama on the other hand becomes relative due to the many reasons. Firstly, its dialogic nature makes it more relatable to the audience and readers. Secondly, the involvement of characters that are often stereotype allows the participants to identify with them and therefore relate situations. Last but not the least drama opens up opportunities for role playing and therefore learning becomes more interesting and engaging.

\section{ACTIVITY}

The case study was conducted in classroom with a population of twenty polytechnic students. However before conducting the same the pre-requisites were considered to ensure effective results:

A. The play chosen for study was of an Indian playwright Vijay Tendulkar. This is so keeping in mind the relativity with the subjects. The plays theme that deals with gender and tribal oppression mingled with a light use of humour seemed appropriate for their understanding. In addition the language applied in the plays also makes it easier for them to participate and understand.

B. A total of twenty students were chosen to participate with a sex ration of 1:1 to ensure a well-balanced unbiased viewpoint.

C. Some students were allotted to play certain characters and were supplied the script of the play beforehand.

D. The plot of the play was explained beforehand to the actors and audiences alike to make the process of interpretation easier and convenient.

\section{V.OBSERVATIONS}

Because the process of teaching-learning has been deviated from the orthodox manner of instruction the teacher constantly needs to be on his/her heels and while conducting the same the following observations were made in the classroom:

A. The students were very enthusiastic to participate due to its interactive nature and due to its deviation from the regular technically infused syllabus.

B. The students actively fulfilled their designated roles and engaged in dialogue delivery with passion and commitment.

C. Due to the realistic theme the participants found it much easier to express themselves without inhibitions.

D. There was also constant peer assistance whenever mistakes were indicated and observed. 


\section{REACTIONS}

The reaction received from the students is perhaps the most important part of the case study. As stated earlier the objective of the study is twofold, that is to identify the positive aspects of Drama to hone communication skills and to raise social consciousness. Therefore after the activity the students were then supplied with questionnaires consisting of around eight questions, some of which deals with queries related to communication skills and others related with social awareness and consciousness. The structure of the questionnaire is given below:

A. Questionnaire:

1. Do you think that introducing drama in the classroom makes language learning interesting?
(a) Yes
(b) $\mathrm{No}$
(c) No Comment

2. Does participating in such an activity give you a sense of confidence in communicating?
(a) Yes
(b) No
(c) No Comment

3. Which skill(s) of language learning do you think was promoted

(a) Speaking (b) Speaking and Listening (c) Speaking, Listening and Non-Verbal Skills

4. Has the activity encouraged you to communicate with other students?

(a) Yes (b) No (c) No comment

5. What do you think was the theme of the play?
(a) A princess's story
Revenge
(b) Oppression

6. Do you think that some of the characters were treated badly by others
(a) Yes
(b) No
(c) No comment

7. Do you think that women are less efficient than men?
(a) Yes
(b) No (c) No Comment

8. Do you think that the social system in India needs any change? If yes, specify two areas.

(a)

\section{RESULTS}

After the completion of the activity, the circulation of the questionnaire and the compilation of the feedback after a brief interaction with the participants, the outcome of the case study could be analysed and the result determined. The feedback determined that majority of the students felt that introducing literature in the form of drama in their language learning classes was necessary as it created an atmosphere of interest. They felt it was a good deviation from the regular technically designed pattern. When asked if the activity has instilled any sense of confidence in communication a few of them reacted positively while others felt they still need more activities like these to address the issue. In reply to the skills that the activity has helped to developed all the participants agreed that the same has enabled them to utilised and helped to promote all the three aspects of communication that is listening, speaking and most importantly non-verbal communicative techniques as it required role playing and acting. In response to whether the activity has promoted interpersonal communication, many agreed that it does while the others had no comment. What was more interesting however was the way in which the students react towards the subject matter of the play. All the students identified oppression as the theme of the play and were even able to pin point the aspect of both gender and tribal oppression that is a core issue in the play. Some of them even went to the extent of relating the incidents in the play with the everyday events in many parts of India. Many however especially the girls were very much affected by the way Princess Vijaya the main protagonists in the play was treated as less than ordinary by her male counterparts. The icing on the cake was however the response that the students gave to the last question where many mentioned the better treatment of women in India as a pivotal issue that needs to be addressed, while the treatment of everyone as equal also as a core area. Quite a number also mentioned the aspect of tribal oppression as a key area that needs to be addressed. During the brief interaction many participants admitted to the fact that they were really affected by the play and after being supplied with facts and figures to prove that these issues are realistic, they immediately reacted towards it. While being asked about ways and means to deal with such situation it was very encouraging to see that each and everyone turned their attention towards education as a key weapon to counter such negative notions and attitudes. The activity had encouraged them to discuss and indulge in a healthy discussion that circled around the eradication of social ills from the social environment which was a very encouraging sign. On the other hand this was done through the medium of communication which was unintentional but was brought about by the engagement in the activity itself.

\section{PROBLEMS ENCOUNTERED}

It is only obvious that the conduct of such a case study in the class would not be a very smooth one. Here too while conducting the same the teacher had to face some challenges some of which are listed below:

A. Since the activity was something new to the students it was very difficult to ensure that it went on smoothly. A lot of time was lost in trying to explain to them the theme and plot of the play, instructing them how to act and read the dialogues as they should be read.

B. A lot of the terms used were beyond their maturity level therefore each term had to be explained in clear terms.

C. Some of the students did not take active part in the activity as they were not very comfortable communicating in the target language.

D. Some students did not know how to react to the situation, therefore the questionnaire was returned half done.

\section{CONCLUSION}

Despite the few problems faced it may be concluded that the objective of conducting the activity was aptly achieved. The positive feedback and interaction of the students shows that such an introduction is welcoming and would alter the process of teaching language and communication skills in the classroom. In addition the consciousness that was displayed through their feedback and interaction shows clearly that the aspects of introducing such patterns promotes a sense of awareness and understanding of the social environment surrounding us and therefore 


\section{Communicating and Resisting Oppression: Using Drama for Communication Skills and Social Consciousness in Language Classrooms}

gives rise to reaction and a move towards social and cultural changes in the society.

\section{REFERENCES}

1. Vijay Tendulkar, 'Dambadwipcha Mukabala' (Encounter in Umbugland) in Five Plays. Trans. by Kumud Mehta and Shanta Gokhale. OUP: Sixteenth Impression, 2014.

2. Alan Maley \& Alan Duff, Drama Techniques: A Resource Book of Communicative Activities for Language Teachers. Cambridge University Press: London, 2005.

3. Susan Holden, Drama in Language Teaching. Harlow Longman: London, 1981

4. Dr. P. Prasad, The Functional Aspects of Communication Skills. $6^{\text {th }}$ edition. S. K. Kataria \& Sons: India, 2015.

5. William J. Long, English Literature: Its History and its Significance for the Life of the English Speaking World. Rupa Publications India, 2015.

6. Levana Saxon, (31 ${ }^{\text {st }}$ Oct 2019). Theory: Theatre of the Oppressed. Available: https://www.beautifultrouble.org

7. (31 ${ }^{\text {st }}$ Oct 2019). Available: https://www.the-artifice.com/in-yer-face theatre-a-contemporary-form-of-drama/

8. Dr. Adeel Khalid, Dr. Craig A Chin, Dr. Mir M Attiqullah, Prof. John F Swelgart, Dr. Beth Stutzmann \& Dr. Wei Zhou, (21 ${ }^{\text {st }}$ October 2019). Building a Better Engineer: The Importance of Humanities in Engineering Curriculum, American Society for Engineering Education. $120^{\text {th }}$ ASEE Annual Conference and Exposition. Available: https://www.asee.org >download

\section{AUTHORS PROFILE}

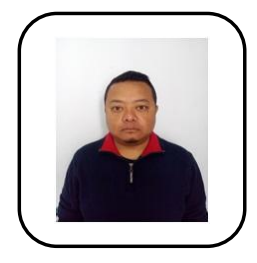

Rangehbok Lyngwa is a $\mathrm{PhD}$ scholar currently pursuing his research on the literary works of Vijay Tendulkar from NIT Meghalaya. He is also a Senior Grade Lecturer teaching Communication Skills and Developmental Life Skills to young diploma students of engineering in Shillong Polytechnic. He has published a number of research papers in reputed international journals and presented papers in various national and international conferences and seminars. He also has a deep interest in poetry and has self published a book of poems entitled 'Looking Glass: Reflections in Verse'.

Dr. Paonam Sudeep Mangang is an Associate Professor and Head of the department of Humanities and Social Sciences at NIT Meghalaya, Shillong. He has done his research on the literary works of Henrik Ibsen and is presently guiding three scholars in their research projects. He has published several research papers in international journals and presented papers in various academic programmes too. He has also organised numerous international conferences, national seminars, workshops and symposia. He is also the Editor of Spectrum, an International journal of Humanities and Social Sciences. 